a medical man of eminence a report of a case of accidental poisoning by colchicum in which the symptoms were identical with those of my patient, and ended, in about the same length of time, in paralysis and death.

P.S.-Since the above was written $I$ have received from my friend, Mr. A. Wynter B!yth, the Devon county analyst, an analysis of these pulls, from which it appears that twenty-eight of them contain more colchicum than has in recorded cases caused death.

North Tawton, Devon.

\section{NOTES OF A CASE IN WHICH THE PRINCI- PAL SYMPTOM WAS A CONSTANT AND COPIOUS DISCHARGE OF WATERY FLUID FROM THE NOSE.}

\section{BY W. R. SPEIRS, M.B. \& C.M.}

HAving observed in the Clinical Society's Transactions for 1879 a case reported by Sir James Paget, in which the principal symptom - a continuous dropping of watery fluid from the nostril-is there described by him as one of great rarity, the following note of a similar case which occurred in my practice may not be without interest.

In Novemher, 1875, T. R-, aged fifty-five, a tailor, of medium height, spare and delicate-looking, consulted me as to a constant dropping of a clear watery fluid from his nose, which was at times so copious that any garment he was making became completely saturated in a very short time. This, he sail, had been going on for nearly a month, and he was at lenuth obliged to give up his work and seek advice It commenced at first with sneezing, which he was inclined to attribute to the inhalation of dust arising from some coarse flaunel upon which he was employed in making jackets for pitmen. Change of work, however, made no difference in the discharge, which went on as before. He could give no account of any injury received previously, and there was neither pain nor swelling at any time during the continuance of the flow. It came drop by drop, but at times almost so quickly as to form a stream; and on one occasion, when I wanted some of the fluid for examination, an egg-cup containing nearly an ounce was filled in a quarter ot an hour. I have no note of the sp. gr. of the fluid, but it was perfectly clear and colourless, free from smell, and, according to the patient, had no taste. It contained no albumen, and a handkerchief thoroughly saturated with the discharge, on being held to the fire and dried, felt as soft and free from any stiffening as one that had not been used. No excoriation of the lip was produced, no matter how long the discharge was allowed to run over it. At night the patient was compelled to have his head raised till he was almost in a sitting posture, as when lying diswn the fluid ran back into his throat and caused a choking sensation. He noticed that the flow abated in some degree, but never quite ceased, when he took exercise in the open air, more especially it the atmosphere was clear and frosty, but inmediately on coming in doors and entering a warm room it assumed its previous proportions. The sense. of smell is now perfect, and was at no time during the flow in any way intelfered with. In this case, as in Sir James Paget's, there was no appearance of disease in the mucous membrane of the nostril, and nothing whatever to indicate the source of the fluid. For nearly nine months the flow continued almust uniformly, certainly without any very decided variation in quantity, in spite of all the treatment adopted. This consisted of glycerine of tannin, tannic acid in powder, and various other astringents locally, whilst the general treatment aimed at acting on the lower bowel by purgatives in the way of counter-irritation. Liquid extract of eryot and jiquor strychniæ were also persevered with for some time; but the case was finally cured (or, at any rate, the dropping ceased gradually day by day, until within a week it had quite disappeared) by keeping the nostrils always filled with goose-grease. Whether in this case the fluid canie from the antrum, as post-mortem examinatiın proved it to do in the case recorded by Sir James Paget, of course I cannot say, but presuming that the cases were illentical, is it possible that the goose-yrease which the patient bimself applied experimentally filled $u \mu$ the fissure of communication between the antrum and middle meatus of the nose, and thereby so altered the existing condition of the structure lining that cavity as to effect a cessation of the excessire secretion? This appears to me to be a reasonable explanation of the result, and quite as satisfactory therapentically as the treatment adopted by Sir Benjamin Brodie, whose case is referred to in Sir James Paget's report, which consisted of injection of solution of sulphate of zinc (three grains to an ounce) into the nostril, while the salt was at the same time administered internally. In the case referred to there were two separate attacks, and, considering that the second lasted twenty-three months presumably under the above treatment, it cannot be considered very satisfactory. Looking at the case anatomically, injection of solution of sulphate of zinc, or any otber fluid, in to the nostril, could not exert much, if any, influence over the lining membrane of the autrum.

The following therapeutic note in connexion with my patient may be worthy of record:-For twenty seven years he suffered martyrdom from piles. He underwent an operation at the hands of a London hospital surgeon without benefit, but has been at length completely relieved from all pain and discomfort attending that condition by steadily persevering with glycerine in drachm doses twice daily, which I preseribed for him about three months ago, after seeing it recommended for that purpose by Dr. Young, of Florence, in the Practitioner for January, 1878.

Haltwhistle.

\section{A afthror}

\section{HOS P I T A P R A T ICE,} BRITISH AND FOREIGN.

Nulla antem est alia pro certo noscendi via, nisi quamplurimss et morbornm et dissectionum historias, tum aliorum tum proprias collectas habere, et inter se comparare.-MoselgNi De Sed. et Caus. Morb, lib. iv. Procmium.

\section{LONDON HOSPITAL.}

HYSTERO-EPILEPSY ; PHASES LIKE THOSE DESCRIBED BY CHARCOT ; OBSTRUCTIVE DYSMENORRHEA ; TREATMENT BY DILATATION OF CERVIX UTERI.

\section{(Under the care of Dr. SANsom.)}

For the following notes we are indebted to Mr. G. T. Stonham, house-physician.

The patient, a fairly intelligent girl, a Roman Catholic, aged twenty-one, was admitted on Aug. 20th, 1880. She lived from the age of thirteen to seventeen in Canada. Her mother's father died of consumption, but there was no neurotic family history. As a child she had good health, but whilst in Canada, and even after, she had suffered much from headaches, and from frequent attacks of vomiting. She first menstruated at the age of eleven; bad always been very irregular; her menses were scanty, lasting never more than three days, and always accompanied by severe pain, both constant and paroxysmal, referred vaguely to the back and to the front of the abdomen, and coming on at the commencement of the flow, and lasting till it ceased.

She was first taken with fits in April, 1850, in which she lay for about five minutes in a rigid condition, and with her eyes shut. She at the same time had great impairment of menory. These fits came on about once a day on an average till the middle of July, when they becane much more frequent, and of a more violent character.

She had five fits on the first day of admission, lasting from a quarter of an hour to an hour, and several similar fits on many days following. A fit could at any time be excited by pressure on the ovaries, aud during its manifestation pressure on the ovaries would either arrest it or alter its character. Pressure on other parts of the body did not produce a fit. They were most frequent about the time of a menstrual period, and she also seemed to be more liable to them afrer being visited by the priest. Between the fits she seemed cheerful and intellinent, but sufiered a good deal at times from headache, which, she said, felt as "though nails were heing hammered into her head."

The fit consisted of a series of stages :- 1 . They began by her head being thrown up, and inclined slightly to the 